\title{
Одномодовый волоконный лазер мощностью 2 кВт
}

\author{
Д.В. Кулаков" \\ Российский Федеральный Ядерный Центр Всероссийский Научно-Исследовательский Институт \\ Технической Физики имени академика Е.И. Забабахина \\ «РФЯЦ-ВНИИТФ» \\ *E-mail: dimcool7@gmail.com
}

DOI:10.31868/RFL2018.45-46

Представлены результаты сборки и экспериментального исследования одномодового волоконного иттербиевого лазера мощностью 2 кВт.

Введение. В современном мире большим спросом пользуются волоконные лазеры, которые имеют ряд преимуществ перед твердотельными и газовыми: компактность; высокий кпд; устойчивость к механическим воздействиям; надежность. Мощные одномодовые волоконные лазеры используются в научноисследовательских целях, промышленности, медицине и в других отраслях.

В настоящее время в России отсутствует производство мощных волоконных лазеров. Следует отметить, что компания НТО «Ирэ-Полюс» г. Фрязино, в которой налажено производство волоконных лазеров и систем является частью международной компании IPG Photonics, расположенной в США. В мире есть опыт по разработке волоконных лазеров с подобными характеристиками, в частности в Китае был собран макет волоконного лазера с оптической мощностью порядка 2 кВт и качеством излучения $\mathrm{M}^{2}$ не хуже 1.37. [1]. Поэтому важной задачей является разработка отечественного волоконного одномодового высокомощного лазера с предельно высоким качеством излучения на собственной элементной базе.

В настоящей работе представлены параметры и схема одномодового волоконного иттербиевого лазера мощностью 2 кВт. Представлены результаты экспериментального исследования лазера.

Общая схема лазера. Лазер собран по схеме задающий генераторусилитель. Общая блок-схема лазера представлена на рисунке 1.

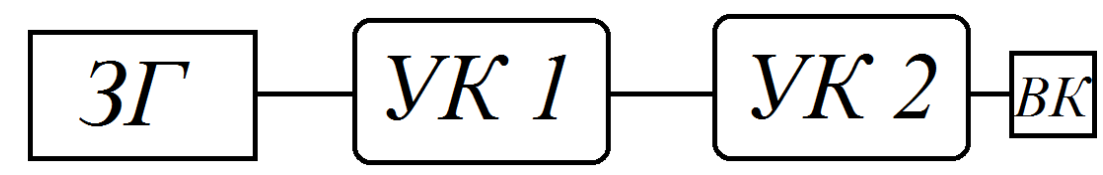

Рис. 1. Общая блок-схема лазера. ЗГ - задающий генератор; УК 1-2 - усилительный каскад первый и второй соответственно; ВК - волоконный кабель.

Схема лазера состоит из задающего генератора мощностью 118 Вт и двух каскадов усиления. Вывод излучения осуществляется с помощью волоконного кабеля с разъемом стандарта QBH.

Задающий генератор. Задающий генератор (ЗГ) представляет собой одномодовый волоконный лазер мощностью 118 Вт. Роль зеркал резонатора выполняет пара брэгговских волоконных решеток (ВБР). В качестве активной среды используется оптическое волокно производства РФЯЦ-ВНИИТФ, легированное иттербием (Yb), с двойной оболочкой, при этом вторая оболочка имеет геометрию восьмигранника. Диаметр сердцевины волокна составляет 10 мкм, а числовая апертура - 0.08. Предотвращение распространения излучения в оболочке волокна на выходе ЗГ осуществляется с помощью волоконного фильтра оболочки. 
Накачка активного волокна осуществляется модулями накачки с длиной волны 976 нм производства РФЯЦ-ВНИИТФ. Выходная мощность ЗГ составила 118 Вт, при этом эффективность «свет» в «свет» 67,5\%. Длина волны излучения 1080 нм, ширина спектра на полувысоте (FWHW) 0,5 нм.

Усилительные каскады и результаты сборки. В усилительных каскадах используется активное волокно с двойной оболочкой, диаметром сердцевины 20 мкм и числовой апертурой 0.06. Ввод излучения накачки в усилительный каскад осуществляется с помощью объединителей накачки (каплеров) двух типов:

1. каплер $7 \mathrm{x} 1$;

2. каплер $(6+1) \times 1$.

Излучение задающего генератора в усилитель вводится с помощью адаптера поля моды. На выходе каждого усилителя установлен фильтр оболочки.

Одной из серьезных технологических проблем сборки мощного волоконного лазера являются теплонагруженные участки волокна, которые требуют дополнительного охлаждения и защиты. Одним из самых опасных участков является сварка между волокном объединителя накачки типа (6+1)х1 и активным волокном усилителя. Эта сварка обеспечивает ввод излучения накачки порядка 1.5 кВт, а сварка каплера со вторым каскадом усиления кроме того должна обеспечить распространения излучения сигнала порядка 1 кВт.

В результате сборки выходная оптическая мощность лазера составила 1970 Вт, при этом эффективность «свет в свет» 67,5\%.

Спектр лазерной генерации на максимальной мощности составил 1080 нм, полушириной $\sim 3$ нм. Помимо основной длины волны в спектре излучения присутсвует компонента вынужденного комбинационного рассеяния (ВКР) с центральной длиной волны 1133,1 нм, полушириной 6 нм. Доля ВКР в спектре излучения не более $20 \%$. Уменьшение длины оптического тракта позволит увеличить порог возникновения ВКР в лазере [2].

Заключение. В ходе данной работы собран макет одномодового иттербиевого волоконного лазера с параметрами:

- мощность $\sim 2$ кВт;

- центральная длина волны излучения 1080нм;

- ширина линии излучения на полувысоте $\sim 3$ нм;

- одномодовый режим генерации;

- КПД «от розетки» 23\%.

По результатам экспериментальной отработки макета выявлены основные недостатки:

- возникновение ВКР вследствие большой длины оптического тракта;

- использование модулей накачки без стабилизации и сужения спектра излучения, что приводит к необходимости использовать большую длину активного волокна;

- использование двух каскадов усиления приводит к потерям излучения на каплерах и, соответственно, к снижению КПД.

Устранение данных недостатков позволит увеличить КПД лазера.

\section{Литература}

[1] W. Wenliang, H. Liangjin, L. Jinyong Inteк. Journal for Light and Electron Optics 9, (2015)

[2] Smith R.G. Appl. Opt. 11, 2489-2494, (1972). 